\title{
ERa-36 regulates progesterone receptor activity in breast cancer
}

\author{
Henri-Philippe Konan ${ }^{1,2,3}$, Loay Kassem ${ }^{4}$, Soleilmane Omarjee ${ }^{1,2,3,5}$, Ausra Surmieliova-Garnès ${ }^{1,2,3}$, \\ Julien Jacquemetton ${ }^{1,2,3}$, Elodie Cascales ${ }^{6}$, Amélie Rezza ${ }^{6}$, Olivier Trédan ${ }^{1,2,3,7}$, Isabelle Treilleux ${ }^{1,2,3,8}$, \\ Coralie Poulard ${ }^{1,2,3}$ and Muriel Le Romancer ${ }^{1,2,3^{*}}$
}

\begin{abstract}
Background: Alterations in estrogen and progesterone signaling, via their respective receptors, estrogen receptor alpha (ERa) and progesterone receptor (PR), respectively, are largely involved in the development of breast cancer (BC). The recent identification of ERa-36, a splice variant of ERa, has uncovered a new facet of this pathology. Although ERa36 expression is associated with poor prognosis, metastasis development, and resistance to treatment, its predictive value has so far not been associated with a BC subtype and its mechanisms of action remain understudied.

Methods: To study ERa-36 expression in BC specimens, we performed immunochemical experiments. Next, the role of ERa-36 in progesterone signaling was investigated by generating KO clones using the CRISPR/CAS9 technology. PR signaling was also assessed by proximity ligation assay, Western blotting, RT-QPCR, and ChIP experiments. Finally, proliferation assays were performed with the IncuCyte technology and migration experiments using scratch assays.

Results: Here, we demonstrate that ERa-36 expression at the plasma membrane is correlated with a reduced diseasefree survival in a cohort of 160 BC patients, particularly in PR-positive tumors, suggesting a crosstalk between ERa-36 and PR. Indeed, we show that ERa-36 interacts constitutively with PR in the nucleus of tumor cells. Moreover, it regulates PR expression and phosphorylation on key residues, impacting the biological effects of progesterone.

Conclusions: $\mathrm{ERa}-36$ is thus a regulator of PR signaling, interfering with its transcriptional activity and progesteroneinduced anti-proliferative effects as well as migratory capacity. Hence, ERa-36 may constitute a new prognostic marker as well as a potential target in PR-positive BC.
\end{abstract}

Keywords: Breast cancer, ERa-36, Progesterone receptor, Transcription, Biomarker

\section{Background}

Breast cancer $(\mathrm{BC})$ is the most common cancer among women worldwide. More than $75 \%$ of breast tumors express the estrogen receptor $\alpha(E R \alpha)$ in the nucleus and predominantly belong to the luminal subtype. ER $\alpha$ plays a major role in $\mathrm{BC}$ tumorigenesis as it regulates cell cycle, cell survival, and angiogenesis [1]. Interfering with the ER $\alpha$ pathway

\footnotetext{
* Correspondence: muriel.leromancer@lyon.unicancer.fr

'Université de Lyon, F-69000 Lyon, France

2 Inserm U1052, Centre de Recherche en Cancérologie de Lyon, Centre Léon Bérard, Bâtiment D, 28 rue Laennec, 69373 Lyon Cedex 08, F-69000 Lyon, France

Full list of author information is available at the end of the article
}

using anti-estrogens (either selective estrogen receptor modulators, such as tamoxifen, or selective estrogen downregulators, such as fulvestrant) or through estrogen deprivation (e.g., aromatase inhibitors) increases the survival of $E R \alpha$ positive $\mathrm{BC}$ patients. Despite the high level of sensitivity of luminal tumors to endocrine therapy, treatment efficacy is limited by intrinsic and acquired resistance [2, 3]. Indeed, $30-50 \%$ of patients relapse in the adjuvant setting and eventually die following the development of metastases [2, 4]. More recently, ER $\alpha-36$, a splice variant of $E R \alpha$, was identified as a novel actor of breast tumorigenesis. ER $\alpha-36$ is encoded by the ESR1 locus, transcribed from a promoter

(c) The Author(s). 2020 Open Access This article is licensed under a Creative Commons Attribution 4.0 International License, which permits use, sharing, adaptation, distribution and reproduction in any medium or format, as long as you give appropriate credit to the original author(s) and the source, provide a link to the Creative Commons licence, and indicate if changes were made. The images or other third party material in this article are included in the article's Creative Commons licence, unless indicated otherwise in a credit line to the material. If material is not included in the article's Creative Commons licence and your intended use is not permitted by statutory regulation or exceeds the permitted use, you will need to obtain permission directly from the copyright holder. To view a copy of this licence, visit http://creativecommons.org/licenses/by/4.0/. The Creative Commons Public Domain Dedication waiver (http://creativecommons.org/publicdomain/zero/1.0/) applies to the data made available in this article, unless otherwise stated in a credit line to the data. 
located in the first intron, resulting in a shortened receptor. ER $\alpha$-36 retains the DNA-binding domain, but lacks both transactivation domains, AF-1 and AF-2. Furthermore, the last 138 amino acids are replaced by a unique 27 amino acid sequence at the C-terminal domain [5]. Compared to ER $\alpha$, $\mathrm{ER} \alpha-36$ displays distinct expression patterns. Indeed, while $E R \alpha$ is mainly expressed in the nucleus of ER $\alpha$-positive tumors, ER $\alpha-36$ is mainly expressed at the level of the plasma membrane of breast tumor cells [6], co-localized with caveolin, a typical cell surface protein [7, 8]. ER $\alpha-36$ was shown to activate ERK1/2 through the protein kinase $C$ delta signaling pathway, leading to an increase in the expression of cyclin D1/CDK4, which increases cell cycle progression [9]. In addition, binding of ER $\alpha-36$ to ERK prevents its dephosphorylation by MKP3 and enhances a paxillin/cyclin D1 pathway [10]. Moreover, ER $\alpha-36$ signaling contributes to the potential invasion and metastatic spread of cancer cells by upregulating aldehyde dehydrogenase 1A1 [11]. Surprisingly, unlike $\mathrm{ER} \alpha, \mathrm{ER} \alpha-36$ is activated by the estrogen antagonist tamoxifen and fulvestrant, both compounds routinely used in ER $\alpha$-positive $\mathrm{BC}$ treatment [8]. Accumulating experimental and clinical evidence supports that $\mathrm{BC}$ may arise from mammary stem/progenitor cells which possess self-renewal abilities. Recently, it was reported that ER $\alpha$-36-mediated estrogen signaling plays an important role in the maintenance of ER $\alpha$-positive and ER $\alpha$-negative breast cancer stem/progenitor cells [12]. Moreover, overexpression of ER $\alpha-36$ in normal mammary epithelial cells causes loss of adhesion, enhanced migration, and resistance to apoptosis [13].

$\mathrm{ER} \alpha-36$ is also a marker of poor prognosis in $\mathrm{BC}$, and its expression is associated with resistance to tamoxifen treatment, probably due to its high expression in stem cells, known to possess intrinsic resistance to treatment $[11,14]$.

The aim of this study was to investigate whether the prognostic value of ER $\alpha-36$ was associated with a particular subtype of BC. We unveiled a correlation between ER $\alpha-36$ expression and poorer PR-positive patient survival, suggesting a functional relationship between ER $\alpha-36$ and PR signaling. We clearly showed that ER $\alpha-$ 36 modulates PR expression and activity, regulating cell proliferation, thus confirming its importance in BC.

\section{Methods}

\section{Cell culture}

T47D were cultured in RPMI-1640 medium, supplemented with $10 \%$ fetal bovine serum (FBS), $2 \%$ penicillinstreptomycin (Life Technologies), and insulin $(10 \mu \mathrm{g} / \mathrm{ml})$. Cos7 cells were maintained in DMEM, supplemented with $10 \%$ FBS and 2\% penicillin-streptomycin (Life Technologies). All cell lines were grown in a humidified atmosphere with $5 \% \mathrm{CO}_{2}$ at $37^{\circ} \mathrm{C}$, authenticated by Eurofins and tested for Mycoplasma infection (Lonza, Rockland, ME, USA).

Prior to experiments, when it was indicated, cells were grown in phenol red-free medium supplemented with
$10 \%$ charcoal-stripped serum (Biowest). Cells were then treated with $10 \mathrm{nM}$ of R5020 (Perkin Elmer) or E2 (Sigma) for the indicated times.

\section{Generation of CRISPR ERa-36 KO cell lines Electroporation of T47D cells}

Cells were grown at subconfluence and electroporated with CRISPR reagents after cell dissociation using the Neon electroporator Invitrogen $1750 \mathrm{~V}-20 \mathrm{~ms}-1$ pulse. Electroporated cells were cultured as single cells to obtain pure clonal populations.

\section{Strategy}

Guide RNAs were designed using an in-house genOway's tool, and those with the highest score were selected.

Targeted sequences were as follows: \#1: 5' TTAATA AGTACACACCGCAG AGG 3'; \#2: 5' CTGTGAGGCC TTATGACCAG AGG 3'.

These guide RNAs were designed to induce the deletion of an ER $\alpha$-36-specific sequence by cutting into intron 8 and downstream of exon 9 (intron 31 and exon 32 with genOway's numbering). ER $\alpha-36$ isoform-specific knockout clones were amplified, and isolated DNA was characterized by PCR amplification, as the 393-bp deleted sequence includes the ER $\alpha$-36-specific exon 9 splice acceptor site, coding sequence, and STOP codon.

\section{Antibodies}

Information of primary antibodies

\begin{tabular}{|c|c|c|c|c|c|}
\hline Antibodies & Supplier & Origin & $\begin{array}{l}\text { Dilution } \\
\text { for WB }\end{array}$ & $\begin{array}{l}\text { Dilution } \\
\text { for PLA }\end{array}$ & $\begin{array}{l}\text { Dilution } \\
\text { for } I H C\end{array}$ \\
\hline ERa-36 & Homemade & Rabbit & $1 / 1000$ & $1 / 100$ & $1 / 50$ \\
\hline PR (AB8) & $\begin{array}{l}\text { Thermo } \\
\text { Scientific }\end{array}$ & Mouse & & $1 / 500$ & \\
\hline PR (H190) & $\begin{array}{l}\text { Santa Cruz } \\
\text { Biotechnology }\end{array}$ & Rabbit & $1 / 2000$ & & \\
\hline p-PRS294 & $\begin{array}{l}\text { Cell Signaling } \\
\text { Technology }\end{array}$ & Rabbit & $1 / 1000$ & $1 / 500$ & \\
\hline p-PR S345 & $\begin{array}{l}\text { Cell Signaling } \\
\text { Technology }\end{array}$ & Rabbit & $1 / 1000$ & $1 / 500$ & \\
\hline Tubulin & Sigma & Mouse & $1 / 10000$ & & \\
\hline V5-tag (D3H8Q) & $\begin{array}{l}\text { Cell Signaling } \\
\text { Technology }\end{array}$ & Rabbit & $1 / 1000$ & & \\
\hline Flag M2 & Sigma & Mouse & $1 / 1000$ & & \\
\hline $\begin{array}{l}\text { p44/42 MAPK } \\
(\text { Erk1/2) }\end{array}$ & $\begin{array}{l}\text { Cell Signaling } \\
\text { Technology }\end{array}$ & Rabbit & $1 / 1000$ & & \\
\hline $\begin{array}{l}\text { Phospho p44/42 } \\
\text { MAPK (Erk1/2) }\end{array}$ & $\begin{array}{l}\text { Cell Signaling } \\
\text { Technology }\end{array}$ & Rabbit & $1 / 1000$ & & \\
\hline
\end{tabular}

\section{Luciferase reporter assay}

HeLa cells $\left(7.5 \times 10^{4}\right)$ were plated in 24 -well plates $24 \mathrm{~h}$ prior to transfection. The transfected DNA included 
$100 \mathrm{ng}$ of reporter plasmid and $25 \mathrm{ng}$ of pRL-TK Renilla luciferase vector (Promega) used as an internal control, together with various amounts of expression vectors, as indicated. Total transfected DNA was kept constant by adding empty pSG5-Flag vectors. The cells were induced with $10 \mathrm{nM}$ R5020 24 $\mathrm{h}$ following transfection, then harvested after an additional $24 \mathrm{~h}$ and assayed for luciferase activity following the manufacturer's instructions. Luciferase activities were normalized against the activity of the internal control Renilla luciferase.

\section{Immunofluorescence}

T47D cells $\left(2 \times 10^{5}\right)$ were grown on coverslips in 12 -well plates. After treatment, cells were fixed in methanol for $2 \mathrm{~min}$ and washed twice in PBS. Non-specific binding was blocked using a $1 \%$ gelatin solution for $30 \mathrm{~min}$ at room temperature. Cells were incubated with PR antibody for $1 \mathrm{~h}$ at $37^{\circ} \mathrm{C}$, subsequently with the secondary antibodies Alexa Fluor 488 anti-mouse (Jackson ImmunoResearch, Cambridge, UK) (1:2000e) and Alexa Fluor 568 anti-rabbit (Invitrogen, Carlsbad, USA) (1:1000e) in Dako diluent for $1 \mathrm{~h}$. Finally, coverslips were mounted on glass slides in mounting solution (Dako, Carpinteria, CA, USA). The fluorescent slides were viewed under the Nikon NIE microscope.

\section{Immunoprecipitation and Western blot analysis}

Cells were lyzed using RIPA buffer $(50 \mathrm{mM}$ Tris $\mathrm{HCl}$, $\mathrm{pH}$ 8, $150 \mathrm{mM} \mathrm{NaCl}, 1 \mathrm{mM}$ EDTA, 1\% NP-40, and $0.25 \%$ deoxycholate) supplemented with protease inhibitor tablets (Roche Molecular Biochemicals) and phosphatase inhibitors $\left(1 \mathrm{mM} \mathrm{NaF}, 1 \mathrm{mM} \mathrm{Na} \mathrm{VO}_{4}\right.$, and $1 \mathrm{mM} \beta$ glycerophosphate). Protein extracts were incubated with primary antibodies overnight at $4{ }^{\circ} \mathrm{C}$ on a shaker. Protein G-Agarose beads were added, and the mixture was incubated for $2 \mathrm{~h}$ at $4{ }^{\circ} \mathrm{C}$. The immunoprecipitated proteins were separated by sodium dodecyl sulfate-polyacrylamide gel electrophoresis (SDS-PAGE) and analyzed by Western blot, then visualized by electrochemiluminescence (ECL, Roche Molecular Biochemicals).

\section{Chromatin immunoprecipitation}

ChIP experiments were performed according to the manufacturer's protocol (SingleChIP enzymatic chromatin IP Kit - Cell signaling) with antibodies against PR, ER $\alpha$, and IgG. Results are expressed relative to the signal obtained with chromatin input. Primer sequences are indicated in the Additional file 1.

\section{RNA extraction and real-time $R T-q P C R$ analysis}

Total RNA $(1 \mu \mathrm{g})$ was extracted and purified using TRI Reagent (Sigma-Aldrich, USA), prior to being reversetranscribed using $100 \mathrm{ng}$ of random primers following the Superscript II (Thermo Fisher, USA) protocol. Real- time PCR was performed with SYBR Green qPCR master mix (BioRad) in a Step One plus real-time PCR detection system (Applied Biosystems). All amplifications were performed in triplicate. Mean values of triplicate measurements were calculated according to the $-\Delta \Delta \mathrm{Ct}$ quantification method and were normalized against the expression of $28 \mathrm{~S}$ ribosomal mRNA as reference. Data were presented as mean \pm SEM. Sequences of the oligonucleotides used are listed in Additional file 2.

\section{Proximity ligation assay, image acquisition, and analysis}

This technology exposes protein/protein interactions in situ [15]. Briefly, cells were seeded and fixed with cold methanol. After saturation, the different couples of primary antibodies were incubated for $1 \mathrm{~h}$ at $37^{\circ} \mathrm{C}$. The proximity ligation assay (PLA) probes consisting of secondary antibodies conjugated with complementary oligonucleotides were incubated for $1 \mathrm{~h}$ at $37^{\circ} \mathrm{C}$. The amplification step followed the ligation of nucleotides for $100 \mathrm{~min}$ at $37^{\circ} \mathrm{C}$. Samples were subsequently analyzed under fluorescence microscopy.

The hybridized fluorescent slides were viewed under a Nikon Eclipse $\mathrm{Ni}$ microscope. Images were acquired under identical conditions at $\times 60$ magnification. Image acquisition was performed by imaging DAPI staining at a fixed $\mathrm{Z}$ Position while a $\mathrm{Z}$ stack of $\pm 5 \mu \mathrm{m}$ at $1 \mu \mathrm{m}$ intervals was carried out. The final image was stacked to a single level before further quantification. On each sample, at least one hundred cells were counted. Analysis and quantification of these samples were performed using the Image software (free access). PLA dots were quantified on 8-bit images using the "Analyse Particles" command, while cells were counted using the cell counter plugin.

IHC images were also acquired using a Nikon Eclipse Ni microscope at $\times 40$ magnification, and PLA dots were quantified as described above.

\section{Glutathione transferase pull-down assay}

ER $\alpha$-expressing plasmids were transcribed and translated in vitro using T7-coupled reticulocyte lysate in the presence of $\left[{ }^{35} \mathrm{~S}\right]$ methionine. Glutathione transferase (GST) fusion proteins were incubated with labeled proteins in $200 \mu \mathrm{l}$ of binding buffer (Tris $20 \mathrm{mM} \mathrm{pH} \mathrm{7.4,}$ $\mathrm{NaCl} 0.1 \mathrm{M}$, EDTA $1 \mathrm{mM}$, glycerol $10 \%$, Igepal $0.25 \%$ with $1 \mathrm{mM}$ DTT and $1 \%$ milk) for $2 \mathrm{~h}$ at room temperature. After washing, bound proteins were separated by SDS-PAGE and visualized by autoradiography.

\section{Proliferation studies}

$4 \times 10^{3}$ cells seeded onto a 96-well plate were plated $5 \mathrm{~h}$ before incubation with the different hormones (E2, $\mathrm{R} 5020$, or ethanol). Images were acquired using an IncuCyte ZOOM over 7 days, and cell proliferation was 
measured as the percentage of cell density observed over this period. Results are represented as graphs indicating the rate of proliferation over time, extrapolated from at least three independent experiments, each performed in triplicate.

\section{Wound healing assay}

Cells were plated in duplicate in 6-well plates and grown to confluence. Wounds were then performed with a p200 pipette tip. After washes to remove cellular debris, three images of each well were taken. The width of the wound was measured at 3 places and recorded as $t=0$. The cells were then allowed to migrate back into the wounded area. After $16 \mathrm{~h}$, the width of the open area was measured. Cell migration was expressed as the percentage of the gap $(t=16)$ relative to the primary width of the open area $(t=0)$. Images were acquired on a phase contrast microscope (Zeiss, Axiovert 25). All experiments were performed in triplicate.

\section{Patient population}

We screened 200 consecutive female patients with operable breast cancers who had undergone radical surgery and received adjuvant/neoadjuvant therapy in the Centre Léon Bérard between January 1999 and December 2001. Paraffin blocks of tumor tissue were available for 182 patients. Among these, we failed to assess ER $\alpha-36$ in 22 tumor specimens as a result of insufficient tumor or tissue loss during TMA preparation. Therefore, a total of 160 specimens were analyzed in this study.

Patients underwent radical surgery (either modified radical mastectomy (MRM) or breast-conserving surgery (BCS) with axillary lymph node (LN) staging). ER $\alpha-66$ and PR were detected by immunohistochemistry, and tumors were considered positive if they display nuclear staining in $10 \%$ or more of the tumor cells. HER2 expression was determined using immunohistochemistry, and tumors were considered positive if they reached $3+$ staining by immunohistochemistry or $2+$ staining with HER2 amplification detected by FISH.

The data exported from patient files for analysis included age, histological subtype, maximum tumor size, number of LNs involved, SBR grade, ER, PR, HER2 status, date of diagnosis, date of relapse, and date of death or last clinical visit. Tumor samples and clinical data were obtained with the approval of the Institutional Review Board. This study is reported according to the REMARK criteria [16].

\section{Immunohistochemical analysis}

The breast tumor samples were inserted as triplicates using a $600-\mu \mathrm{m}$ needle into 4 tissue microarray (TMA) blocks. The blocks containing invasive carcinoma were sectioned at a thickness of $4 \mu \mathrm{m}$. After deparaffinization and rehydration, endogenous peroxidases were blocked by incubating the slides in $5 \%$ hydrogen peroxide in sterile water. For heat-induced antigen retrieval, tissue sections were boiled in $10 \mathrm{mM}$ citrate buffer $\mathrm{pH} 6.0$ (Dako, Trappes, France) using a water bath at $98{ }^{\circ} \mathrm{C}$ for 50 min.

The slides were then incubated at room temperature for $1 \mathrm{~h}$ with the antibodies against ER $\alpha$-36 (rabbit polyclonal antibody). These antibodies were diluted using an antibody diluent solution (Chemmate, Dako, Trappes, France) at $1 / 50$. After rinsing in PBS, the slides were incubated with a biotinylated secondary antibody bound to a streptavidin peroxidase conjugate (LSAB+ Kit, Dako, Trappes, France). Bound antibodies were detected by adding the substrate 3,3-diamino-benzidine. Sections were counterstained with hematoxylin.

Blinded to the clinical data, biomarker expression was evaluated by 2 observers who assessed both the percentage and the intensity of the membranous staining for ER $\alpha-36$ in the infiltrative carcinomatous cells only (faint cytoplasmic staining which was found in almost all malignant cells was not considered).

For scoring purposes, the highest intensity of staining in malignant cells was divided into 3 levels ( 0 , no staining; 1 , weak staining; 2 , moderate to strong staining), and the percentage of stained cells was also classified into 3 levels ( 0 , no stained cells; 1 , staining in less than half of the malignant cells; 2 , staining in half or more of the malignant cells). Then, both intensity and percentage scores were added to obtain a single score (from 0 to 4) in a manner similar to the Allred score for ER and PR staining [17]. For the purpose of correlation and survival analyses, tumors were considered to have a low expression for ER $\alpha$-36 if they scored between 0 and 2 and were considered to have high expression above 2 .

\section{Statistical analysis}

The correlation between ER $\alpha-36$ expression and clinicopathologic characteristics was determined using Pearson's chi-square test (or Fisher's exact test). Distant metastasis-free survival (DMFS) was defined as the time from the date of histological diagnosis of breast cancer to the date of distant metastasis or death. Disease-free survival (DFS) was defined as the time from the date of histological diagnosis of breast cancer to the date of any cancer recurrence (local, distant, or contralateral) or death. Overall survival (OS) was defined as the time from the date of histological diagnosis of breast cancer to the date of death. The database was locked at 12 years of follow-up, and patients who were event-free at the last follow-up visit (or at 12 years) were censored.

Survival curves, median DMFS, DFS, and OS (if reached) in addition to 8-year DMFS, DFS, and OS (with 95\%CIs) were derived from Kaplan-Meier estimates, and 
the curves were compared using log-rank test. Hazard ratios and 95\%CIs were calculated using Cox regression model. Cox multivariate analysis was performed to determine whether a factor is an independent predictor of DMFS, DFS, or OS after adjusting for other significant factors at the univariate level. All statistical tests were two-sided, and the $p$ value was considered statistically significant if inferior to $5 \%$. Statistical analyses were performed using SPSS 20.0 statistics package.

\section{Results}

\section{Clinico-pathological characteristics}

We evaluated ER $\alpha-36$ expression in a cohort of patients displaying invasive breast cancer using our polyclonal antibody specifically recognizing the ER $\alpha-36$ isoform, which has already been validated for IHC experiments [10]. Table 1 summarizes the clinico-pathological characteristics of the patient cohort tested. For the 160 assessable patients, the median follow-up interval was 10 years (ranging from 0.2 to 12 years). Median age at diagnosis was 56.9 years (ranging from 30.4 to 87.4 years). Regarding tumor stage, $57.5 \%$ of patients displayed tumors exceeding $20 \mathrm{~mm}$, and $52.5 \%$ had axillary lymph node (LN) metastases. $16.3 \%$ of the patients had SBR grade I tumors, $44.4 \%$ had grade II tumors, and 39.4\% grade III tumors. Adjuvant chemotherapy was administered to $63.1 \%$ of patients, while $83.1 \%$ received adjuvant hormonal therapy.

\section{Pattern of ERa-36 expression}

Regarding the immunohistochemical (IHC) analysis of $E R \alpha-36$, most of the tumors displayed a faint diffuse cytoplasmic ER $\alpha-36$ expression (Fig. 1a), which for the purpose of statistical analysis was discarded. However, only 65 tumors $(40 \%)$ had a high membrane expression, while $95(60 \%)$ had a low or were devoid of membrane expression (Fig. 1a). The correlation between ER $\alpha$-36 expression and different clinico-pathological parameters was then statistically investigated (Table 2). No significant association was observed between high ER $\alpha-36$ and age, menopausal status, tumor size, ER $\alpha-66$ status, PR status, and axillary lymph node metastasis, except for high SBR grade (grade III) $(p=0.04)$.

\section{High ERa-36 expression predicts poorer outcome in BC}

At 8 years, rates of distant metastasis-free survival (DMFS), disease-free survival (DFS), and overall survival (OS) were all poorer in patients with high compared to low ER $\alpha-36$ expression, with $59.0 \%$ versus $76.6 \%$ (DMFS: $\mathrm{HR}=2.02,95 \% \mathrm{CI} 1.2-3.4, p=0.007), 54.7 \%$ versus $70.9 \%$ (DFS: $\mathrm{HR}=1.69,95 \% \mathrm{CI} 1.1-2.7, p=0.029$ ), and $68.6 \%$ versus $79.6 \%$ (OS: $\mathrm{HR}=1.82,95 \% \mathrm{CI} 1.02-3.2, p=0.040$ ), respectively (Fig. 1b). In the multivariate analysis, when adjusted to tumor size, LN metastasis, and SBR grade
Table 1 Clinico-pathological characteristics, treatment received, and ERa-36 expression in the patient cohort tested (160 patients)

\begin{tabular}{|c|c|c|c|}
\hline Characteristic & & Number & Percent \\
\hline \multirow[t]{2}{*}{ Age group (years) } & $<50$ & 51 & 31.9 \\
\hline & $>50$ & 109 & 68.1 \\
\hline \multirow[t]{2}{*}{ Menopausal status } & Pre & 57 & 35.6 \\
\hline & Post & 103 & 74.4 \\
\hline \multirow[t]{2}{*}{ Tumor size $(\mathrm{cm})$} & $<2$ & 68 & 42.5 \\
\hline & $>2$ & 92 & 57.5 \\
\hline \multirow[t]{2}{*}{ Axillary LN metastasis } & No & 76 & 47.5 \\
\hline & Yes & 84 & 52.5 \\
\hline \multirow[t]{3}{*}{ SBR grade } & 1 & 26 & 16.3 \\
\hline & $\|$ & 71 & 44.4 \\
\hline & III & 63 & 39.4 \\
\hline \multirow[t]{3}{*}{ ERa-66 status } & Negative & 14 & 8.8 \\
\hline & Positive & 145 & 90.6 \\
\hline & Missing & 1 & \\
\hline \multirow[t]{3}{*}{ PR status } & Negative & 40 & 25.3 \\
\hline & Positive & 118 & 74.7 \\
\hline & Missing & 2 & \\
\hline \multirow[t]{3}{*}{ HER2 status } & Negative & 129 & 84.9 \\
\hline & Overexpressed & 23 & 15.1 \\
\hline & Missing & 8 & \\
\hline \multirow[t]{4}{*}{ Breast cancer subtype } & Luminal & 142 & 91.6 \\
\hline & Basal & 10 & 6.5 \\
\hline & HER2 driven & 3 & 1.9 \\
\hline & Missing & 5 & \\
\hline \multirow[t]{2}{*}{ Adjuvant Hormonal treatment } & No & 27 & 16.9 \\
\hline & Yes & 133 & 83.1 \\
\hline \multirow[t]{2}{*}{ Adjuvant (or neoadj) chemotherapy } & No & 59 & 36.9 \\
\hline & Yes & 101 & 63.1 \\
\hline \multirow[t]{2}{*}{ ERa-36 } & Low & 95 & 59.4 \\
\hline & High & 65 & 40.6 \\
\hline
\end{tabular}

(other significant prognostic factors in the univariate model), high ER $\alpha-36$ expression was still an independent predictor of poorer DMFS ( $\mathrm{HR}=1.93,95 \% \mathrm{CI} 1.1-3.3$, $p=0.016)$ with a tendency towards poorer $\mathrm{OS}(\mathrm{HR}=$ 1.65, 95\%CI 0.9-3.0, $p=0.09$ ). In addition to ER $\alpha-36$, large tumor size $(\mathrm{HR}=1.84,95 \% \mathrm{CI} 1.04-3.28, p=0.04)$ and high SBR grade $(\mathrm{HR}=2.04,95 \% \mathrm{CI} 1.2-3.5, p=$ $0.008)$ were also an independent predictor of poor DMFS in the same multivariate model.

Interestingly, the impact of ER $\alpha-36$ expression on distant metastasis-free relapse was limited to PR-positive patients (Fig. 1c). Indeed, in the PR-positive patient cohort, the 8-year DMFS rate was $57.2 \%$ in patients with high ER $\alpha-36$ expression compared to $84.7 \%$ in patients 

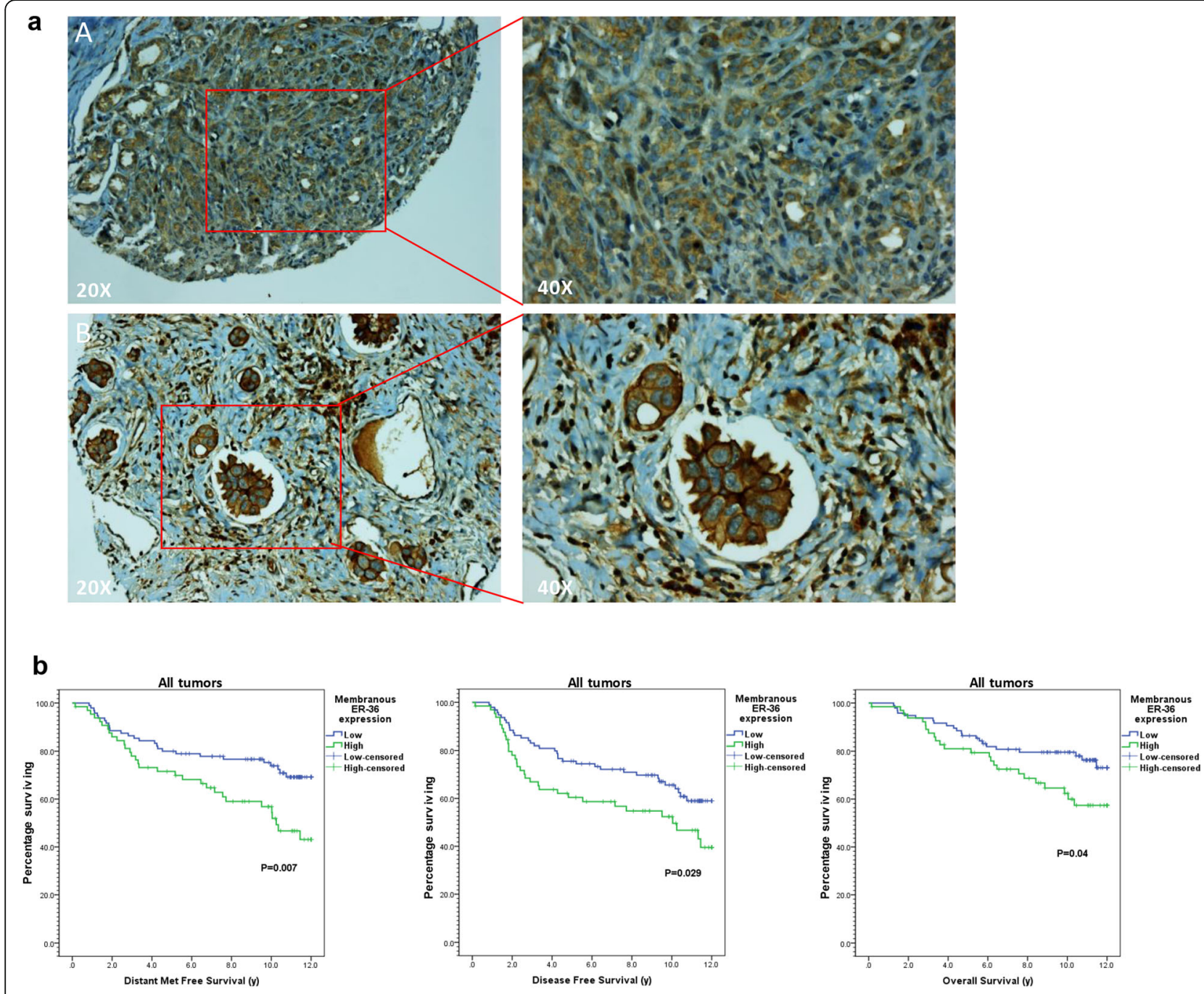

\section{C}
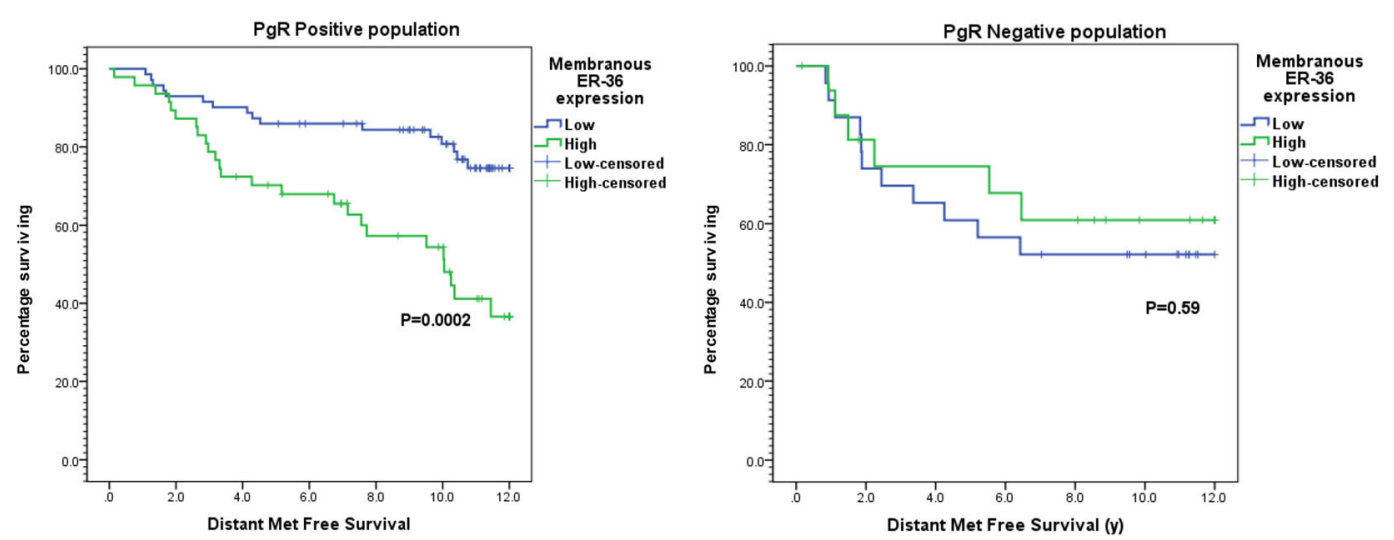

Fig. 1 Expression of ERa-36 in breast tumors. a ERa-36 expression was analyzed by immunohistochemistry (IHC) on formalin-fixed human tumors. Representative images of different IHC staining profiles are shown (A: low expression; B: high expression). $\mathbf{b}$ Kaplan-Meier estimates of diseasemetastases free survival (DMFS) (left), disease-free survival (DFS) (middle), and overall survival (OS) (right) in patients with low (blue) versus high (green) membranous ERa-36 expression. c Kaplan-Meier estimates of DMFS in patients with low (blue) versus high (green) ERa-36 expression in 2 groups of patients according to PR expression 
Table 2 Correlation between ERa-36 expression and clinico-pathological features

\begin{tabular}{|c|c|c|c|c|}
\hline$\underline{\text { Variable }}$ & & ERa-36 low, no. (\%) & ERa-36 high, no. (\%) & $p$ value \\
\hline Age (years) & Mean (+ SD) & $56.6(+12.3)$ & $57.9(+12.9)$ & $0,43^{+}$ \\
\hline \multirow[t]{2}{*}{ Age groups } & $<50$ years & $32(33.7 \%)$ & 19 (29.2\%) & 0.5 \\
\hline & $>50$ years & $63(66.3 \%)$ & $46(70.8 \%)$ & \\
\hline \multirow[t]{2}{*}{ Side } & Right & $42(44.2 \%)$ & $30(46.2 \%)$ & 0.8 \\
\hline & Left & $53(55.8 \%)$ & 35 (53.8\%) & \\
\hline \multirow[t]{2}{*}{ T. size } & $<2 \mathrm{~cm}$ & 41 (43.2\%) & $27(41.5 \%)$ & 0.83 \\
\hline & $>2 \mathrm{~cm}$ & $54(56.8 \%)$ & 38 (58.5\%) & \\
\hline \multirow[t]{2}{*}{ LN met } & Negative & 45 (47.4\%) & 31 (47.4\%) & 0.9 \\
\hline & Positive & $50(52.6 \%)$ & $34(52.3 \%)$ & \\
\hline \multirow[t]{3}{*}{ SBR grade } & Gr 1 & $13(13.7 \%)$ & $13(20 \%)$ & $0.039^{+\dagger}$ \\
\hline & Gr 2 & $50(52.6 \%)$ & $21(32.3 \%)$ & \\
\hline & Gr 3 & $32(33.7 \%)$ & 31 (47.7\%) & \\
\hline \multirow[t]{2}{*}{ ERa status } & Negative & $9(9.6 \%)$ & $5(7.7 \%)$ & $0.7^{++}$ \\
\hline & Positive & 85 (90.4\%) & $60(92.3 \%)$ & \\
\hline \multirow[t]{2}{*}{ PR status } & Negative & $23(24.5 \%)$ & $17(26.6 \%)$ & 0.7 \\
\hline & Positive & 71 (75.5\%) & $47(73.4 \%)$ & \\
\hline \multirow[t]{4}{*}{ ERa/PR detailed } & $\mathrm{ERa}+/ \mathrm{PR}+$ & 71 (75.5\%) & $47(73.4 \%)$ & $0.78^{+\dagger}$ \\
\hline & $\mathrm{ERa}+/ \mathrm{PR}-$ & $14(14.9 \%)$ & $12(18.8 \%)$ & \\
\hline & $\mathrm{ERa}-/ \mathrm{PR}+$ & $0(0.0 \%)$ & $0(0.0 \%)$ & \\
\hline & $\mathrm{ERa}-/ \mathrm{PR}-$ & $9(9.6 \%)$ & $5(7.8 \%)$ & \\
\hline \multirow[t]{2}{*}{ Her 2 status } & Negative & 78 (85.7\%) & $51(83.6 \%)$ & 0.7 \\
\hline & Over-expressed & $13(14.3 \%)$ & $10(16.4 \%)$ & \\
\hline
\end{tabular}

Tam tamoxifen, $A$ l aromatase inhibitor, Anthra anthracycline

*Correlations tested using Pearson's chi-square test ( 2 sided) unless otherwise specified

${ }^{\dagger}$ Difference between means using the Student $t$ test

${ }^{+\dagger}$ Fisher's exact test

with low ER $\alpha-36$ expression $(p<0.001)$. On the contrary, in the PR-negative cohort, the difference in this rate was non-significant with values of $60.7 \%$ and $52.2 \%$ in high versus low ER $\alpha-36$ expression $(p=0.59)$, respectively.

Altogether, these results show that ER $\alpha-36$ expression at the plasma membrane is a poor prognostic marker impacting survival of PR-positive BC patients.

\section{ERa-36 is a new partner of PR}

Based on the previous results, we hypothesized that $E R \alpha$ 36 could be a bad prognostic marker in PR-positive BC because it interferes with progesterone signaling. To evaluate whether these proteins interacted directly, we initially conducted a GST pull-down experiment. We found that radioactive PR specifically interacts with the full length $\mathrm{ER} \alpha-36$ and its truncated form $\mathrm{ER} \alpha-36 \Delta \mathrm{C}$ (truncated C-terminal part), but not with the GST (Fig. 2a). By separating the PR protein into 5 fragments (PR1 to PR5), we further identified PR3 and PR5 fragments, as the sites of ER $\alpha-36 / P R$ interaction (Fig. $2 b$ ). We also validated the interaction by co-immunoprecipitation after transfection of both proteins into Cos7 cells (Fig. 2c). In addition, we investigated this interaction and its localization in T47D cells that express both proteins, using proximity ligation assay (PLA) and specific antibodies. The images obtained revealed red dots in the nucleus of T47D cells, illustrating the interaction of ER $\alpha-36$ with PR independently of progesterone treatment (Fig. 2d-f). The downregulation of PR silencing its expression was performed to validate the specificity of the ER $\alpha-36 / P R$ interaction.

In conclusion, this nuclear interaction suggests that ER $\alpha-36$ could regulate PR transcriptional activity.

\section{ERa-36 regulates PR expression}

To further investigate the role of ER $\alpha-36$ in progesterone signaling, we used the CRISPR/CAS9 technology to specifically knock out the exon coding the isoform. Genomic DNA sequencing of ER $\alpha-36 \mathrm{KO}$ clones of T47D cells revealed deletion at the targeted site. By RT-PCR, we evaluated the mRNA expression of the different clones and chose F4 for wild type (WT) and A6 and G3 for KO clones (Fig. 3a). Next, we assessed the PR expression by Western blot and observed a significant decrease in $\mathrm{KO}$ cells compared to WT cells (Fig. 3b). This effect 


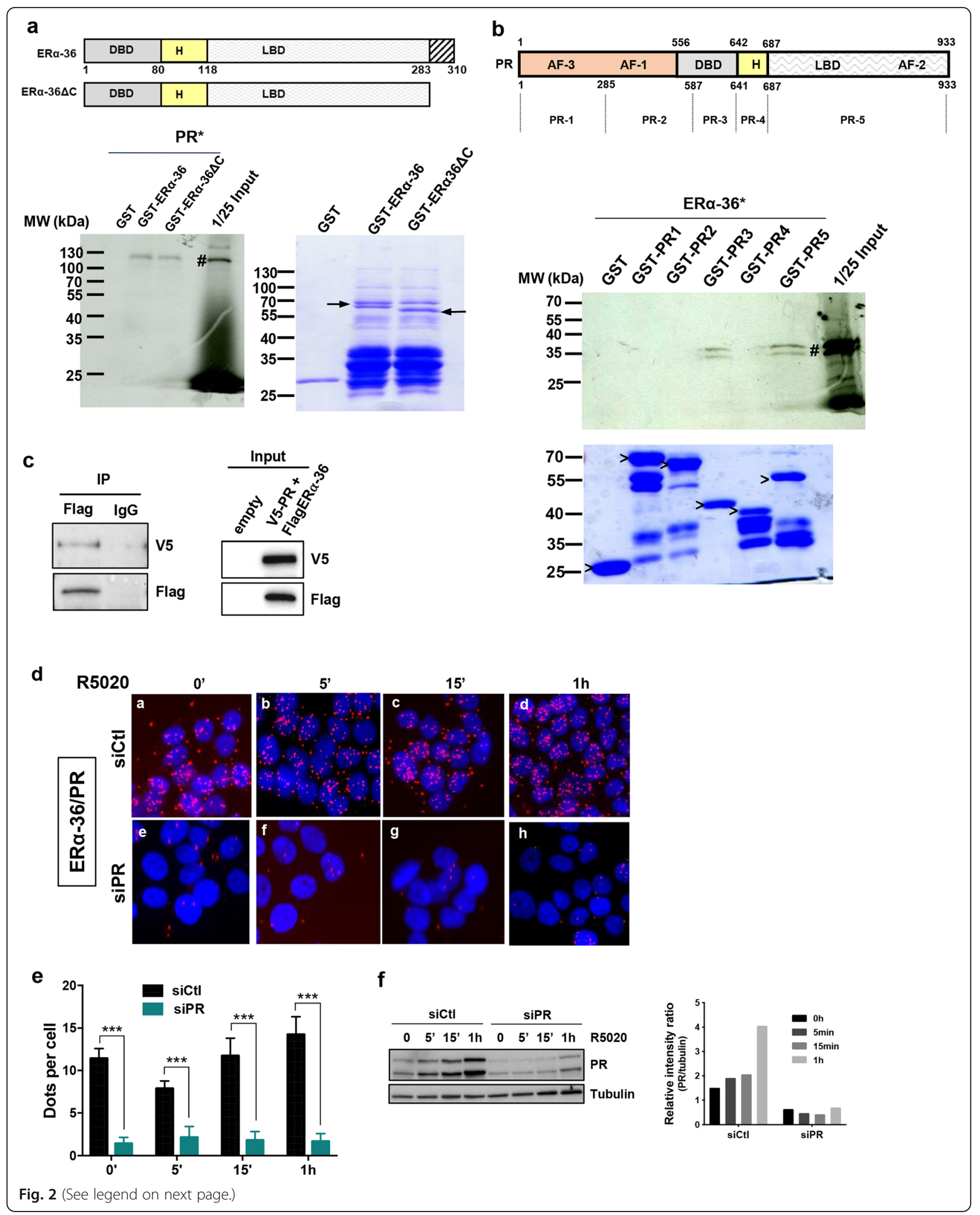


(See figure on previous page.)

Fig. 2 ERa-36 interacts with PR. a A radioactive GST pull-down assay was performed by incubating in vitro ${ }^{35}$ S-labeled PR (PR \#) with GST, GSTERa-36, and GST-ERa-36 $\mathrm{C}$. The corresponding Coomassie-stained gel is shown below. Arrows indicate the full-length fusion proteins. $\mathbf{b}$ PR was divided into 5 fragments (PR1 to PR5). Radioactive ERa-36 (ERa-36 \#) was incubated with the different domains of PR fused to GST, and the bound proteins were visualized by autoradiography. The corresponding Coomassie-stained gel is shown below. " $>$ " indicates the full-length fusion proteins. c pSG5Flag-ERa-36 and pCDNA3V5-PR were overexpressed in Cos7 cells. Cell lysates were immunoprecipitated with the anti-Flag antibody, and the presence of ERa-36 and PR was visualized by Western blot using the anti-Flag and anti-V5 antibodies, respectively. The lower panel shows the expression of the different proteins in the input. $\mathbf{d}$ Proximity ligation assay (PLA) was used to detect the cellular co-localization of endogenous ERa-36 and PR in T47D, grown on coverslips in 12-well plates. Cells were transfected with control siRNA (siCtl) or with siRNA against PR (siPR) and treated for the indicated times with $10 \mathrm{nM}$ of R5020. PLA for ERa-36/PR interaction was performed with anti-PR- and antiERa-36-specific antibodies. The nuclei were counterstained with DAPI (blue) (Obj, $\times 60)$. The detected interactions are represented by red dots. e Quantification of the number of signals per cell was performed using computer-assisted analysis, as reported in the "Methods" section. The mean \pm SD of one experiment representative of three experiments is shown. $\mathbf{f}$ The efficacy of PR siRNA treatment analyzed by Western blot analysis is shown in the left-hand panel and quantified in the right-hand panel where the PR expression relative to tubulin was quantified using ChemiDoc MP (Biorad)

was not due to a decrease in ER $\alpha$ expression, as evidenced by the Western blot (Fig. 3b). We also studied PR localization, which revealed that although the staining decreased in $\mathrm{KO}$ compared to WT clones, it remained within the nucleus (Fig. 3c). We then confirmed that this decrease in $\mathrm{PR}$ expression occurred in $\mathrm{KO}$ cells at the mRNA level by RT-qPCR (Fig. 3d). We hypothesized that this decrease could be due to a defect of ER $\alpha$ binding to the PR promoter, but the low level of $\mathrm{ER} \alpha$ binding on the chromatin did not allow us to conclude (Additional file 3).

\section{ERa-36 regulates PR signaling}

Next, we investigated whether ER $\alpha-36$ regulates progesterone signaling. First, we treated T47D cells with R5020, the progesterone analog for different periods of time and performed Western blot analyses to measure the ERK activation and PR phosphorylation on its main sites: S294 and S345. As shown in Fig. 4a, although pPR S294 and S345 decreased in KO ER $\alpha-36$ clones compared to the WT, P-ERK remained activated. Quantification of the $\mathrm{pPR} / \mathrm{PR}$ ratio showed that ER $\alpha-36 \mathrm{KO}$ reduced the phosphorylation of PR. Treating T47D cells with an ERK inhibitor showed that ERK activity was partially implicated in the phosphorylation of PR (Additional file 4). The decrease in $\mathrm{pPR}$ was confirmed by PLA, showing that both $\mathrm{PPR}$ in the nucleus are lower in KO clones compared to the WT T47D cells (Fig. 4b, c).

We also assessed whether ER $\alpha-36$ regulates PR transcriptional activity, by performing reporter luciferase assays. We found that ER $\alpha-36$ stimulates PR activity in a dose-dependent manner (Fig. 5a). Next, we verified the expression of known PR target genes, which appeared to be downregulated (Fig. 5b and Additional file 5), upregulated (Fig. 5c), or unchanged (Fig. 5d) in ER $\alpha-36 \mathrm{KO}$ clones compared to the WT clone. To evaluate whether these variations in gene expression were related to a change in PR binding, we performed ChIP experiments with $\mathrm{PR}$ antibody and found that $\mathrm{PR}$ binding to chromatin was not significantly modified in KO ER $\alpha-36$ versus WT clones for all genes targeted irrespective of their level of expression (Fig. $5 \mathrm{e}-\mathrm{g}$ ).

In conclusion, ER $\alpha-36$ regulates the PR transcriptional activity independently of PR binding to chromatin.

\section{ERa-36 regulates progesterone-mediated cell proliferation and migration}

The effects of ER $\alpha-36$ on cell proliferation were next assessed using the IncuCyte technology. We found that $E R \alpha-36$ has no major impact on the proliferation of T47D cells (Additional file 6). Although numerous studies have shown that PR is an important actor of breast tumorigenesis and progression [18-20], progesterone can also inhibit FBS- and E2-induced cell proliferation [21-23]; we wondered whether ER $\alpha-36$ was involved in this process. Of note, we found that the inhibitory effect of R5020 on serum-induced proliferation was lost in ER $\alpha-36 \mathrm{KO}$ compared to WT clones (Fig. 6a). Interestingly, ER $\alpha-36$ was also involved in R5020 regulation of E2-induced proliferation. Indeed, while R5020 inhibited the effects of E2 on cell growth in WT cells, this effect on cell proliferation was abolished in ER $\alpha-36 \mathrm{KO}$ cells (Fig. 6b). The mechanism seems to be independent of $\mathrm{ER} \alpha / \mathrm{PR}$ interaction since $\mathrm{ER} \alpha-36 \mathrm{KO}$ does not impair their interaction (Additional file 7). Next, we investigated whether ER $\alpha-36$ played a role in the effect observed for progesterone on cell migration. We found that ER $\alpha-36$ KO significantly impeded cell migration of T47D cells in the presence of R5020 (Fig. 6c, d).

Altogether, these results clearly demonstrate that ER $\alpha$ 36 is involved in PR expression, signaling, and transcriptional activity, highlighting a new regulator of progesterone signaling.

Figure 6e summarizes a model established according to our findings presenting the mechanisms of action of ER $\alpha-36$ on progesterone signaling. Consistently, this splice variant of ER $\alpha$ regulates PR phosphorylation by participating in the activation of an as yet 


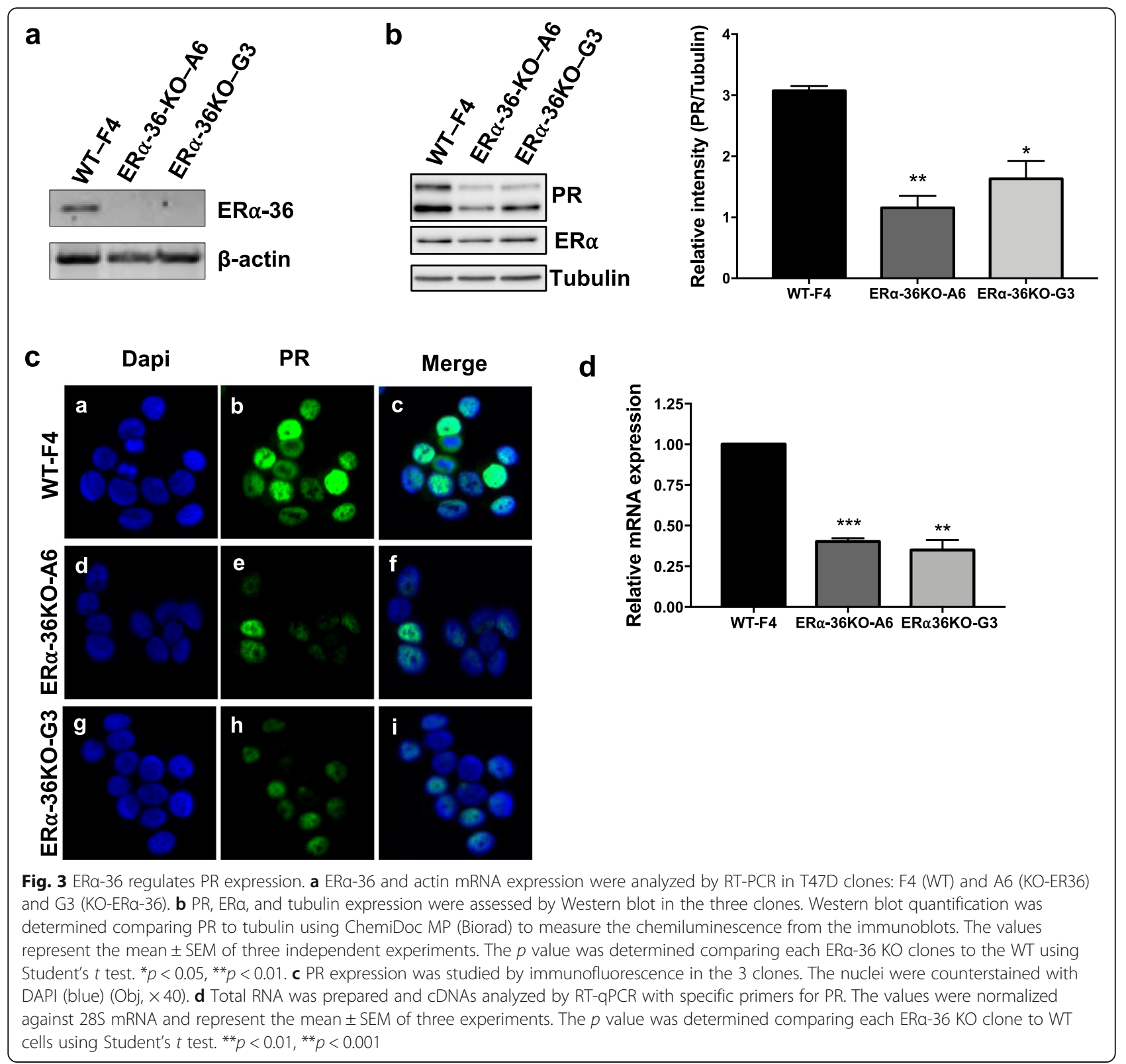

unidentified kinase, and is also involved in its transcriptional activity, modulating the expression of genes participating in progesterone-mediated cell proliferation and migration.

\section{Discussion}

ER $\alpha-36$, the well-characterized splice variant of ER $\alpha$ plays an important role in breast tumorigenesis, and its expression has been associated with poor patient survival, owing primarily to its involvement in tamoxifen resistance and metastasis development [11]. However, its prognostic value has as yet not been studied in different BC subtypes. In this work, based on a cohort of breast cancer patients, we analyzed the expression of ER $\alpha-36$ alongside patient outcome and traditional prognostic markers and reveal that its poor predictive value is significantly associated with PR-positive tumors. Moreover, we identify ER $\alpha-36$ as an important actor of progesterone signaling, modulating its expression, transcriptional activity, and anti-proliferative and migratory function in breast cancer cells.

We herein found that while ER $\alpha-36$ is weakly expressed in the cytoplasm of almost all tumors, its membrane expression occurs only in $40 \%$ of breast tumors independently of ER $\alpha$ and PR status. These results corroborate previous studies on ER $\alpha-36$ expression in BC $[11,14]$. In addition, its expression was associated with a high SBR grade and a decrease in patient survival 


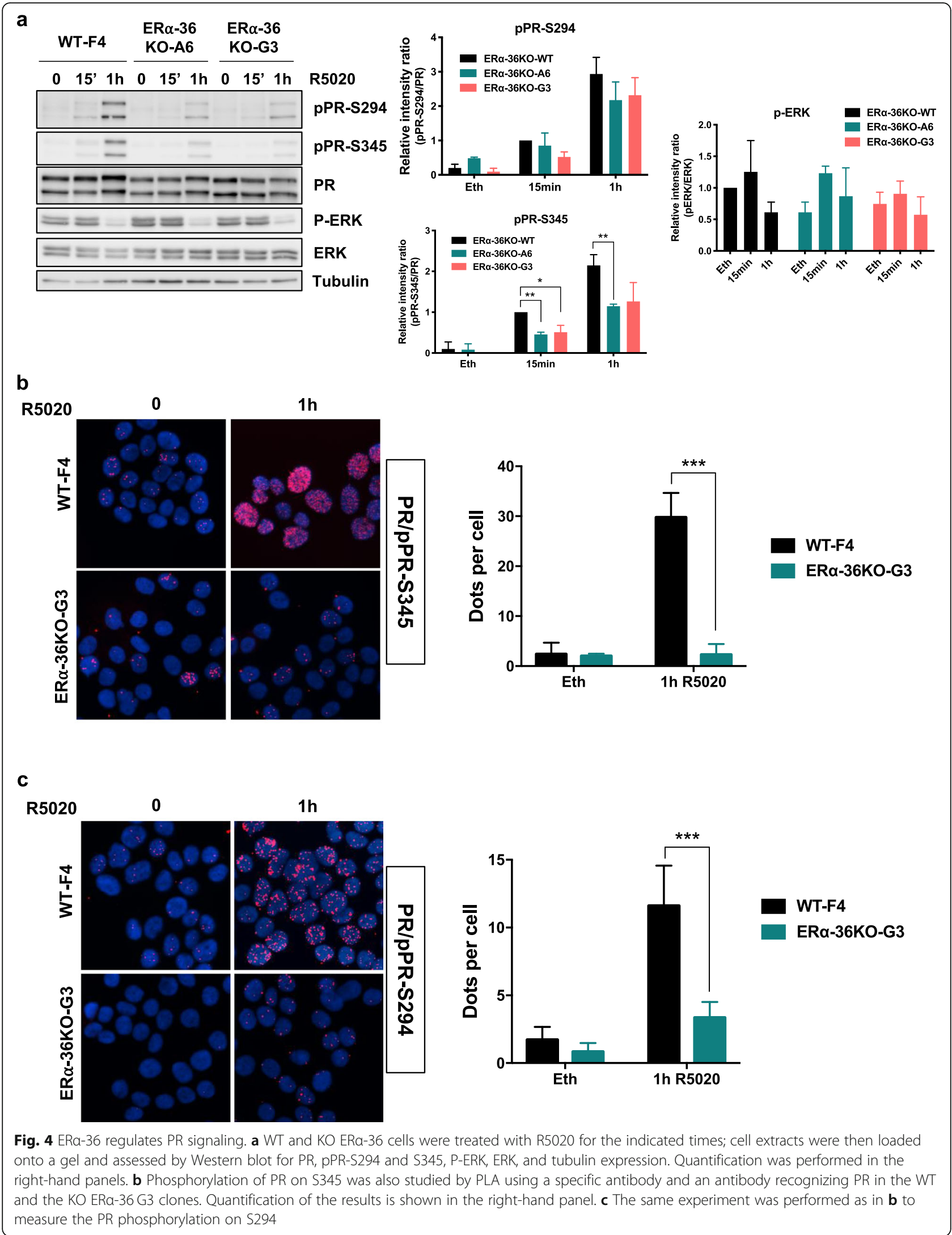




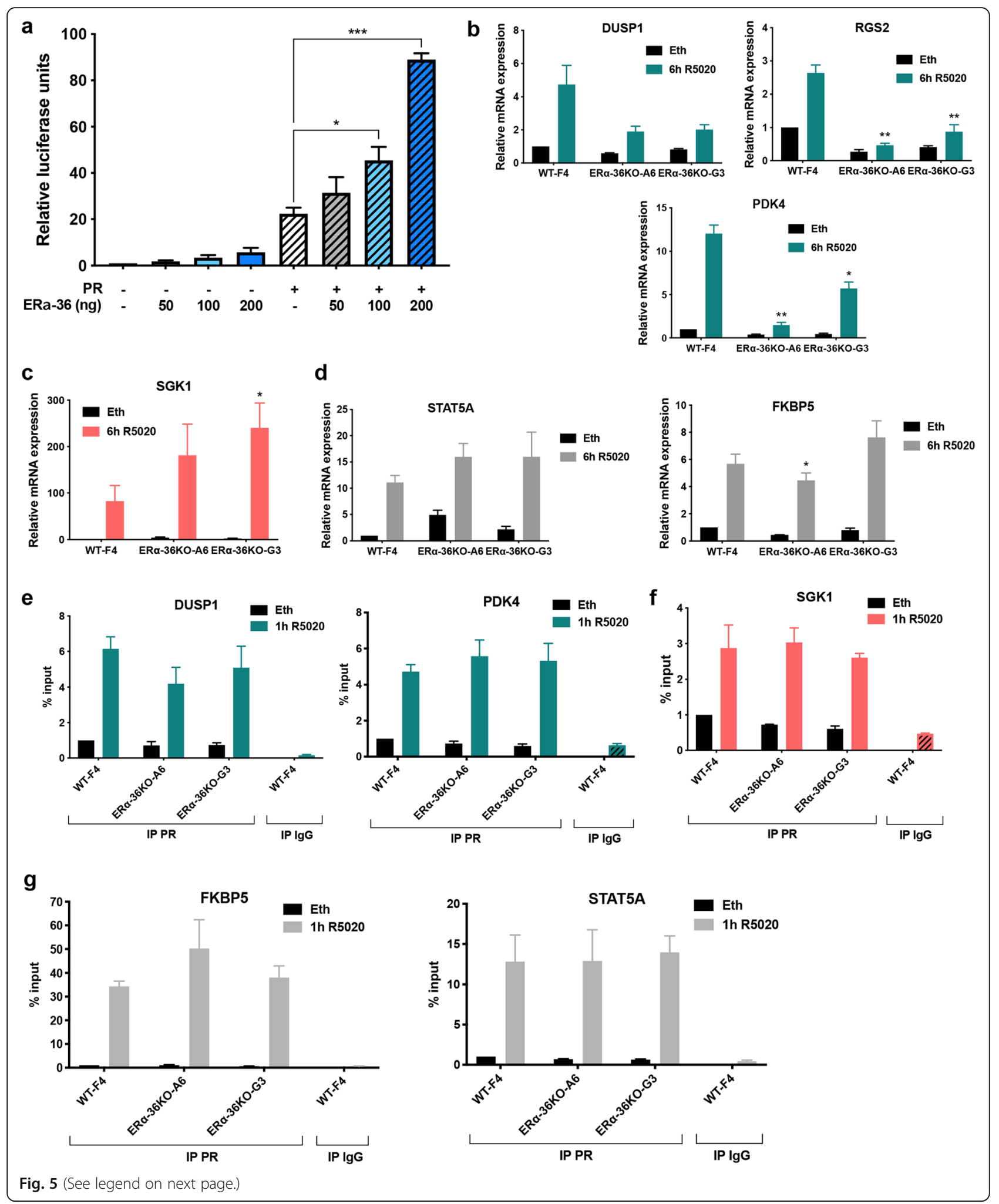


(See figure on previous page.)

Fig. 5 ERa-36 regulates PR transcriptional activity. a HeLa cells were transiently transfected with MMTV-LUC reporter plasmid and expression vectors encoding PR (10 ng) and ERa-36 (from 50 to $200 \mathrm{ng}$ ) using Lipofectamine 2000. Transfected cells were grown in a hormone-free medium for $48 \mathrm{~h}$ in the presence or absence of $10 \mathrm{nM}$ R5020, and extracts of the harvested cells were tested for luciferase activity using the Promega luciferase assay kit. The results were normalized as indicated and presented as the mean \pm SEM of at least three independent experiments. The $p$ value was determined using Student's $t$ test. ${ }^{*} p<0.05$, ${ }^{* *} p<0.001$. b-d Clones of T47D were treated, or not (Eth), $6 \mathrm{~h}$ with $10 \mathrm{nM}$ of R5020. Total RNA was prepared and CDNAs analyzed by RT-qPCR with specific primers for SGK1, STAT5A, FKBP5, PDK4, DUSP1, and RGS2. The values were normalized against $28 \mathrm{~S}$ mRNA and represent the mean \pm SEM of three experiments. The $p$ value was determined comparing each ERa-36 KO clones to the corresponding condition in the WT using Student's $t$ test. ${ }^{* *} p<0.01,{ }^{* * *} p<0.001$. e- $\mathbf{g}$ T47D clones, grown in a charcoal-stripped serum for $48 \mathrm{~h}$ and then treated with $10 \mathrm{nM}$ R5020 for $1 \mathrm{~h}$, were subjected to ChIP assay using an anti-PR antibody. The precipitated DNA fragments were used for qPCR analysis using specific primers for the indicated promoters. The results are expressed relative to the signal obtained from input chromatin. The mean \pm SEM of at least three experiments is shown. The $p$ value determined by comparing each ERa-36 KO clone to the corresponding condition in WT cells using Student's $t$ test was not significant

in terms of OS, DFS, and DMFS, supporting published results showing that ER $\alpha-36$ is associated with the development of metastases [11]. Of interest, we determined that its prognostic value is significant in PR-positive tumors versus PR-negative tumors, suggesting that ER $\alpha-36$ could interfere with PR signaling. This observation, despite based on a retrospective analysis of a single cohort, is a door opener to dissect the details of the interaction between the 2 proteins. By several approaches, we clearly demonstrated that ER $\alpha-36$ binds to PR. Interestingly, its C-terminal domain is not involved in this interaction, indicating that it interacts with PR via a domain shared with ER $\alpha$. We also identified that the interaction between ER $\alpha-36 / P R$ occurs via its binding to 2 domains of PR, namely PR3 and PR5, containing the DBD and the LBD, respectively. The binding sites are different from those of ER $\alpha$, as it binds to 2 sites within the PR sequence located within PR1 and PR2 domains [24]. This may explain why ER $\alpha-36 \mathrm{KO}$ does not impede $\mathrm{ER} \alpha$ binding to PR (Sup. Fig. 3).

Interestingly, although ER $\alpha-36$ is mainly localized in the cytoplasm and at the plasma membrane of cells, it interacts with PR exclusively in the nucleus of cells, suggesting that ER $\alpha-36$ could regulate the transcriptional activity of PR. Indeed, ER $\alpha-36$ has already been shown to regulate the transcription of $A L D H 1 A 1$ by binding to its promoter [11].

We also showed that ER $\alpha-36$ regulates PR expression at the level of the mRNA. The low level of ER $\alpha$ recruitment on PR promotor in T47D cells did not allow to conclude whether this effect is mediated through ER $\alpha$. As miRNAs have been shown to control PR expression $[25,26]$, we can hypothesize that ER $\alpha-36$ could regulate miRNA expression to modulate PR level within the cells.

Interestingly, we found that phosphorylation of PR on S294 and S345 strongly decreased in cells KO for ER $\alpha-$ 36 , indicating that $E R \alpha-36$ may regulate the expression and/or activity of kinases. However, although ERK was described to phosphorylate these 2 residues, the kinase is not involved in our present study as p-ERK was not modified in cells KO for ER $\alpha-36$, although PR phosphorylation strongly decreased, and the ERK inhibitor did not change the phosphorylation status of PR (Sup. Fig. 2).

Given the fact that ER $\alpha-36$ binds PR in the nucleus and that S294 and S345 are involved in the transcriptional activity of PR [27-29], we also assessed whether ER $\alpha$-36 could regulate PR-mediated transcription. A luciferase assay confirmed that ER $\alpha-36$ activates the transcriptional activity of PR on an artificial promoter and is involved in the expression of several PR target genes, including DUSP1, RGS2, and PDK4 (downregulated); SGK1 (upregulated); and FKBP5 (unchanged). However, Chip experiments showed that PR binding remains constant for the genes tested. As we found that ER $\alpha-36$ binds to the $\mathrm{E}$ domain of $\mathrm{PR}$, which contains binding sites for coregulators, we can hypothesize that ER $\alpha-36$ could modulate the binding of coregulators in a genedependent manner.

We also assessed whether ER $\alpha-36$ could play a role in the effects of progesterone on cell proliferation. The role of progesterone in breast tumorigenesis is complex as there is a differential effect of PR in normal and malignant breast tissue [30]. Although administration of PR agonist MPA to mice promotes the formation of mammary tumors initiated by DMBA [31], it exerts a biphasic response in cell lines, such as a rapid proliferation burst followed by a sustained growth arrest [32-34]. More recently, several articles clearly showed that in addition to proliferative action, under certain circumstances, progesterone has also an anti-proliferative action in cellulo and in vivo $[22,34,35]$. Interestingly, although $E R \alpha-36$ has no striking effect on cell growth, we found that its depletion abolished the inhibitory effect of progesterone on FBS- and E2-dependent cell proliferation. As Carroll's team demonstrated that this effect involves PR/ER $\alpha$ interaction [22], we investigated whether this interaction is modified in cells knock-out for ER $\alpha$-36, but no difference was observed, suggesting that other mechanisms of regulation may be involved. Indeed, Sartorius's team found that the inhibitory effect of progesterone on cell proliferation is largely due to a direct binding of PR to 


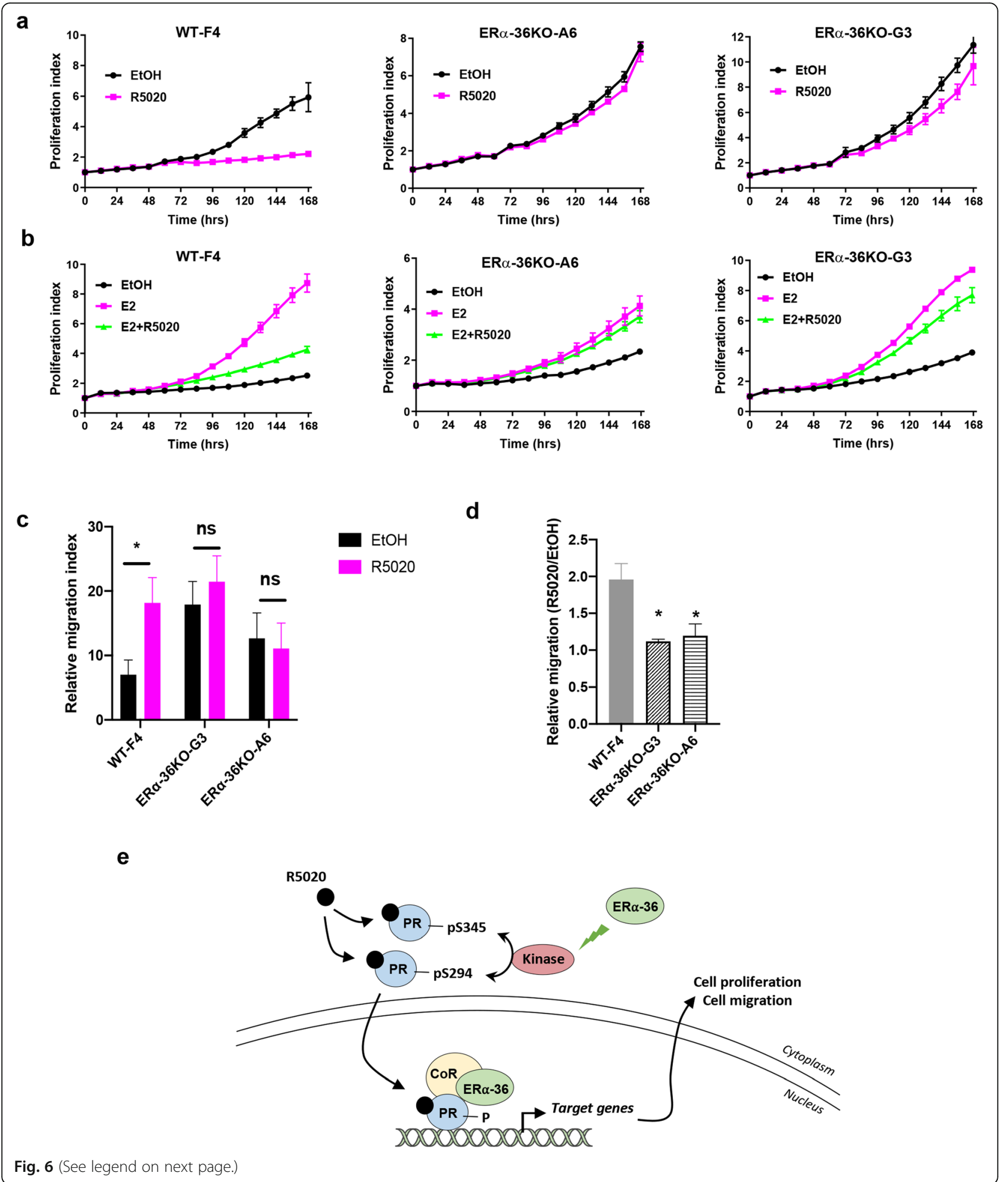


(See figure on previous page.)

Fig. 6 ERa-36 regulates progesterone-mediated cell proliferation. a T47D clones were plated onto 96-well plates and treated with R5020 (10 nM) or ethanol, and proliferation was measured using the IncuCyte technology. Image acquisition was conducted every hour using the IncuCyte software, which calculates the percentage of cell confluency as a function of time over 7 days. The results are represented as graphs showing the rate of proliferation every $24 \mathrm{~h}$. The mean \pm SD of one experiment representative of three experiments is shown. $\mathbf{b}$ The same experiment was performed, but the cells were steroid-deprived and treated with E2 (10 nM), R5020 (10 nM), or both. c Wound healing assays were performed in T47D clones WT or KO for ERa-36 as described in the "Methods" section. The percent of migration was determined as the mean of the distance of the wound for the different experiments. The analysis was performed in three separate experiments. Data are represented as means \pm SEM from three replicates in each of the three independent experiments. ${ }^{*} p<0.05$; ns, non-significant. $\mathbf{d}$ Using the wound healing assay performed in c, the relative migration R5020-dependent was calculated as the mean \pm SEM for the three independent experiments. ${ }^{*} p<0.05$. e Model of ERa36 regulation of PR signaling. Upon progesterone treatment, ERa-36 activates a kinase involved in the phosphorylation of PR at S294 and S345 residues. ERa-36 could participate in coregulator recruitment to regulate PR transcriptional activity in a gene-dependent manner, which in turn modulates cell proliferation and migration. CoR, coregulators

the RNA polymerase III, regulating tRNA transcription affecting gene sets at the translational level [35]. More recently, Vicent's team showed that progesterone negatively regulates cell proliferation via a functional crosstalk with the transcription factor $\mathrm{C} / \mathrm{EBP} \alpha$ [34]. Interestingly, we found that the progesterone-induced C/EBP $\alpha$ expression was dependent on ER $\alpha-36$. In addition, DUSP1 was reported to mediate inhibitory effects of progesterone on cell proliferation [21,34], and our present work describes that ER $\alpha-36 \mathrm{KO}$ also inhibit progesterone-induced DUSP1 transcription, potentially explaining how progesterone fails, at least in part, to inhibit FBS- and E2-dependent cell proliferation in ER $\alpha-36 \mathrm{KO}$ cells.

In conclusion, we demonstrate herein that $\mathrm{ER} \alpha-36$ is involved in progesterone anti-proliferative and migratory effects. This latter could explain why in our study ER $\alpha$ 36 expression in PR-positive tumors is associated with a reduced distant metastasis-free survival.

Altogether, our present data show that ER $\alpha-36$ is a new regulator of PR, concomitantly acting on its expression and its activity. Further studies are required to validate its use as a new biomarker for a subset of PRpositive tumors with poor prognosis.

\section{Conclusions}

In conclusion, we confirmed that ER $\alpha 36$ expression at the plasma membrane is a marker of poor prognosis. However, its correlation with patient survival is only observed in PR-positive tumors.

We also found that ER $\alpha 36$ regulates the signaling and transcriptional activity of progesterone in cellulo. Moreover, ER $\alpha 36$ is required for allowing the antiproliferative effect of progesterone as well as its role in cell migration. Further studies are required to decipher whether other biological processes are altered.

\section{Supplementary information}

Supplementary information accompanies this paper at https://doi.org/10. 1186/s13058-020-01278-7.

Additional file 1. : List of the primers used for RT-PCR experiments.
Additional file 2. : List of the primers used for Chip-qPCR.

Additional file 3. : Study of ERa binding to PR regulatory sequences.

Additional file 4. : Effect of ERK inhibitor on PR phosphorylation.

Additional file 5. : ERa-36 regulates PR transcriptional activity.

Additional file 6. : ERa-36 does not modify T47D cell proliferation.

Additional file 7. : Study of PR/ERa interaction.

\section{Abbreviations}

BC: Breast cancer; ERa: Estrogen receptor a; PR: Progesterone receptor; DMFS: Distant metastasis-free survival; DFS: Disease-free survival; OS: Overall survival; Tam: Tamoxifen; Al: Aromatase inhibitor; Anthra: Anthracycline; PLA: Proximity ligation assay; Eth: Ethanol

\section{Acknowledgements}

We would like to thank B. Manship for proofreading the manuscript and C. Languilaire, F. Nasri, A. Colombe, and L. Odeyer for the technical support. We also thank Marie Norbert for the advice.

\section{Authors' contributions}

Conceptualization: MLR, CP. Methodology: HPK, SO, AS, JJ, IT, EC. AR generated the KO clones. Analysis: MLR, CP, LK, IT, and OT. Supervision: MLR and CP. Writing and review: MLR, CP, and LK. Funding acquisition: MLR. The authors read and approved the final manuscript.

\section{Funding}

We thank INCA and DGOS for the financial support of the project, PDC from the Cancéropole CLARA for JJ's wages, Fondation de France for CP's wages and the government of Ivory Coast for HPK's wages.

Availability of data and materials

All data are available within the article. All materials are available from the authors upon request.

\section{Ethics approval and consent to participate}

Not applicable

\section{Consent for publication}

Not applicable

\section{Competing interests}

The authors declare that they have no conflict of interest.

\section{Author details}

${ }^{1}$ Université de Lyon, F-69000 Lyon, France. ${ }^{2}$ Inserm U1052, Centre de Recherche en Cancérologie de Lyon, Centre Léon Bérard, Bâtiment D, 28 rue Laennec, 69373 Lyon Cedex 08, F-69000 Lyon, France. ${ }^{3}$ CNRS UMR5286, Centre de Recherche en Cancérologie de Lyon, F-69000 Lyon, France. ${ }^{4}$ Clinical Oncology Department, Faculty of Medicine, Cairo University, Cairo, Egypt. ${ }^{5}$ Cancer Research UK, Cambridge Institute, University of Cambridge, Cambridge CB2 ORE, UK. ${ }^{6}$ genOway, 69007 Lyon, France. ${ }^{7}$ Medical Oncology 
Department, Centre Léon Bérard, F-69000 Lyon, France. ${ }^{8}$ Pathology Department, Centre Léon Bérard, F-69000 Lyon, France.

Received: 16 December 2019 Accepted: 13 April 2020 Published online: 19 May 2020

\section{References}

1. Santen RJ, Boyd NF, Chlebowski RT, et al. Critical assessment of new risk factors for breast cancer: considerations for development of an improved risk prediction model. Endocr Relat Cancer. 2007;14(2):169-87.

2. Musgrove EA, Sutherland RL. Biological determinants of endocrine resistance in breast cancer. Nat Rev Cancer. 2009;9(9):631-43.

3. Ring A, Dowsett M. Mechanisms of tamoxifen resistance. Endocr Relat Cancer. 2004;11(4):643-58.

4. Zhang XH, Giuliano M, Trivedi MV, Schiff R, Osborne CK. Metastasis dormancy in estrogen receptor-positive breast cancer. Clin Cancer Res. 2013;19(23):6389-97.

5. Wang $Z$, Zhang $X$, Shen $P$, et al. Identification, cloning, and expression of human estrogen receptor-alpha36, a novel variant of human estrogen receptor-alpha66. Biochem Biophys Res Commun. 2005;336(4):1023-7.

6. Wang $Z$, Zhang $X$, Shen $P$, et al. A variant of estrogen receptor-a, hER-a36: transduction of estrogen- and antiestrogen-dependent membrane-initiated mitogenic signaling. Proc Natl Acad Sci U S A. 2006;103(24):9063-8.

7. Chaudhri RA, Olivares-Navarrete R, Cuenca N, et al. Membrane estrogen signaling enhances tumorigenesis and metastatic potential of breast cancer cells via estrogen receptor-a36 (ERa36). J Biol Chem. 2012;287(10):7169-81.

8. Lin SL, Yan LY, Zhang XT, et al. ER-a36, a variant of ER-a, promotes tamoxifen agonist action in endometrial cancer cells via the MAPK/ERK and PI3K/Akt pathways. PLoS One. 2010;5(2):e9013.

9. Tong JS, Zhang QH, Wang ZB, et al. ER-a36, a novel variant of ER-a, mediates estrogen-stimulated proliferation of endometrial carcinoma cells via the PKCdelta/ERK pathway. PLoS One. 2010;5(11):e15408.

10. Omarjee S, Jacquemetton J, Poulard C, et al. The molecular mechanisms underlying the ERa-36-mediated signaling in breast cancer. Oncogene. 2017;36(18):2503-14

11. Wang $Q$, Jiang J, Ying $G$, et al. Tamoxifen enhances stemness and promotes metastasis of ERa36(+) breast cancer by upregulating ALDH1A1 in cancer cells. Cell Res. 2018;28(3):336-58.

12. Deng $H$, Yin $L$, Zhang XT, et al. ER-a variant ER-a36 mediates antiestrogen resistance in ER-positive breast cancer stem/progenitor cells. J Steroid Biochem Mol Biol. 2014;144(Pt B):417-26.

13. Thiebaut C, Chamard-Jovenin C, Chesnel A, et al. Mammary epithelial cell phenotype disruption in vitro and in vivo through ERalpha36 overexpression. PLoS One. 2017;12(3):e0173931.

14. Shi L, Dong B, Li Z, et al. Expression of ER-a36, a novel variant of estrogen receptor $\mathrm{a}$, and resistance to tamoxifen treatment in breast cancer. J Clin Oncol. 2009;27(21):3423-9.

15. Soderberg O, Gullberg M, Jarvius M, et al. Direct observation of individual endogenous protein complexes in situ by proximity ligation. Nat Methods. 2006:3(12):995-1000.

16. McShane LM, Altman DG, Sauerbrei W, et al. Reporting recommendations for tumor marker prognostic studies (remark). Exp Oncol. 2006;28(2):99-105.

17. Allred DC, Bustamante MA, Daniel CO, Gaskill HV, Cruz AB Jr. Immunocytochemical analysis of estrogen receptors in human breast carcinomas. Evaluation of 130 cases and review of the literature regarding concordance with biochemical assay and clinical relevance. Arch Surg. 1990; 125(1):107-13

18. Diep CH, Daniel AR, Mauro LJ, Knutson TP, Lange CA. Progesterone action in breast, uterine, and ovarian cancers. J Mol Endocrinol. 2015;54(2):R31-53.

19. Knutson TP, Lange CA. Tracking progesterone receptor-mediated actions in breast cancer. Pharmacol Ther. 2014;142(1):114-25.

20. Ogba N, Manning NG, Bliesner BS, et al. Luminal breast cancer metastases and tumor arousal from dormancy are promoted by direct actions of estradiol and progesterone on the malignant cells. Breast Cancer Res. 2014; 16(6):489.

21. Chen CC, Hardy DB, Mendelson CR. Progesterone receptor inhibits proliferation of human breast cancer cells via induction of MAPK phosphatase 1 (MKP-1/DUSP1). J Biol Chem. 2011;286(50):43091-102.

22. Mohammed $H$, Russell IA, Stark $R$, et al. Progesterone receptor modulates ERa action in breast cancer. Nature. 2015;523(7560):313-7.
23. Zheng ZY, Bay BH, Aw SE, Lin VC. A novel antiestrogenic mechanism in progesterone receptor-transfected breast cancer cells. J Biol Chem. 2005: 280(17):17480-7.

24. Ballare $\mathrm{C}$, Uhrig $\mathrm{M}$, Bechtold $\mathrm{T}$, et al. Two domains of the progesterone receptor interact with the estrogen receptor and are required for progesterone activation of the c-Src/Erk pathway in mammalian cells. Mol Cell Biol. 2003;23(6):1994-2008.

25. Cochrane DR, Jacobsen BM, Connaghan KD, et al. Progestin regulated miRNAs that mediate progesterone receptor action in breast cancer. Mol Cell Endocrinol. 2012;355(1):15-24.

26. Gilam A, Shai A, Ashkenazi I, et al. MicroRNA regulation of progesterone receptor in breast cancer. Oncotarget. 2017;8(16):25963-76.

27. Dressing GE, Knutson TP, Schiewer MJ, et al. Progesterone receptor-cyclin D1 complexes induce cell cycle-dependent transcriptional programs in breast cancer cells. Mol Endocrinol. 2014;28(4):442-57.

28. Faivre EJ, Daniel AR, Hillard CJ, Lange CA. Progesterone receptor rapid signaling mediates serine 345 phosphorylation and tethering to specificity protein 1 transcription factors. Mol Endocrinol. 2008;22(4):823-37.

29. Hagan CR, Daniel AR, Dressing GE, Lange CA. Role of phosphorylation in progesterone receptor signaling and specificity. Mol Cell Endocrinol. 2012; 357(1-2):43-9.

30. Carroll JS, Hickey TE, Tarulli GA, Williams M, Tilley WD. Deciphering the divergent roles of progestogens in breast cancer. Nat Rev Cancer. 2017; 17(1):54-64.

31. Aldaz CM, Liao QY, LaBate M, Johnston DA. Medroxyprogesterone acetate accelerates the development and increases the incidence of mouse mammary tumors induced by dimethylbenzanthracene. Carcinogenesis. 1996;17(9):2069-72.

32. Groshong SD, Owen Gl, Grimison B, et al. Biphasic regulation of breast cancer cell growth by progesterone: role of the cyclin-dependent kinase inhibitors, p21 and p27(Kip1). Mol Endocrinol. 1997;11(11):1593-607.

33. Musgrove EA, Swarbrick A, Lee CS, Cornish AL, Sutherland RL. Mechanisms of cyclin-dependent kinase inactivation by progestins. Mol Cell Biol. 1998; 18(4):1812-25.

34. Nacht AS, Ferrari $R$, Zaurin $R$, et al. C/EBPalpha mediates the growth inhibitory effect of progestins on breast cancer cells. EMBO J. 2019;38(18): e101426.

35. Finlay-Schultz J, Gillen AE, Brechbuhl HM, et al. Breast cancer suppression by progesterone receptors is mediated by their modulation of estrogen receptors and RNA polymerase III. Cancer Res. 2017;77(18):4934-46.

\section{Publisher's Note}

Springer Nature remains neutral with regard to jurisdictional claims in published maps and institutional affiliations.

Ready to submit your research? Choose BMC and benefit from:

- fast, convenient online submission

- thorough peer review by experienced researchers in your field

- rapid publication on acceptance

- support for research data, including large and complex data types

- gold Open Access which fosters wider collaboration and increased citations

- maximum visibility for your research: over $100 \mathrm{M}$ website views per year

At $\mathrm{BMC}$, research is always in progress.

Learn more biomedcentral.com/submissions 